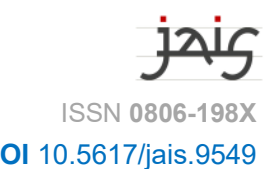

\title{
Young vs. Settled
}

\author{
By ALBReCht HofHeINZ
}

"How old are you? 29!? What have you achieved? What do you plan to build your life on?", a concerned middle-aged man from Alexandria upbraids his son in Little Eagles, a documentary about the filmmaker's problematic relationship with his father. Dad wants to see his son in a proper job feeding a family, and hopes that going to the mosque and memorising passages from the Qur'an might help — while the son is afraid of merely repeating the same old pattern as his father. The son wants to experience life emotionally, to taste it, to take part in improving it, to feel friendship and love. He is dreaming of a world open to many possibilities, a world where one can try out many roles and gain self-confidence through one's own achievements combined with the trust granted by the older generation, a world where one does not have to sacrifice this dream of personal fulfilment for a stale stability. The father, however, displays utter incomprehension for this dream. He wants his son to settle down [yastaqirr]. To be settled means to have a stable income and a suitable place to house a family [ $\lambda$ Apartment Wanted ], to marry, beget children, and pay for their upbringing, enduring all hardship along the way, suffering silently if one must. Emotional relations, emotional development, personal fulfilment, are all subdued to this goal. The emblem of this settling-down is the father quitting school at age 10 to get the first safe job he was offeredas a state-employed clothing presser-and remain in this safety for the rest of his life, flattening all ups and downs that come his way. Growing up in such a world, the son is left gazing out the window, melancholically longing for a positive father-figure he could look up to and aspire to imitate [ $\nearrow$ Father Figures], an engaged father, a father with ideals, ideals that he would want his children to carry on: a father who would want his children to fly. Alas, in the society he finds himself in, only a minority of parents try to help their children to become "Little Eagles". So most, eventually, end up settling down, visiting "the drowned continent of their youth" (HANDAL) only in occasional daydreams [ 7 Freedom vs. Constraint; $\lambda$ Past $v s$. Present]. Writer AḤMAD NĀĞİ uses strong words when he denounces this demand to "live like your parents have lived." He calls the representatives of the old established order "zombies" and decries "the magnitude of the authority the zombie fathers possess and the immense pressure young people are under [...] to assume a single path in life, a future that includes nothing but marriage and bearing children in a cycle of reproducing more zombies."

Social reproduction is, indeed, what the young are expected to accomplish. In principle, the young are allowed to dream of a bright future - but they should use this dreaming drive to establish themselves as responsible adults. In theory, a period of youth - of dreaming, growing, and preparing - is followed by a period of achievement: of established adulthood. Establishing oneself (another way of translating yastaqirr) is thus the goal that drives the actions of most men. This norm is socially and morally so firmly rooted that it is seldom questioned, and whatever the inner doubts and struggles that individuals may experience, the majority strives hard to conform in realising "full conventional adulthood" (SCHIELKE). Tension - also inner tension - arises first and foremost from the economic impossibility for

Journal of Arabic and Islamic Studies • 21 (2021) - Themed Section In2016: *375_*380 (C) Albrecht Hofheinz, Dept. of Culture Studies and Oriental Languages (IKOS), University of Oslo, NO 
many to achieve this goal by the time men (for the economic burden is conventionally placed on them) turn thirty [ $\pi$ Male $v s$. Female]. Youth unemployment (around 35\% in both Egypt and Tunisia according to official figures [WORLD BANK]) is a major problem. "32 and not able to marry," al-Mașrī al-Yawm titles its outlook onto the new year (IBTIHĀL USĀMA). Men often have to postpone marrying until they are $35-40$ or even 45 , ten years later than what used to be normal (SCHIELKE; in Tunisia, recent statistics reveal that over $80 \%$ of men aged 25-29 are single [N. N., JUMHŪRIYYA]). The normal reality, therefore, is to abnormally postpone 'real' adulthood. And in order to settle down, many need to move, to the city, to the Gulf [ $\nearrow$ Migration], where they lead a life in suspense, "not for its own sake [...], but for something to come in the future" (SCHIELKE, also for the rest of this paragraph). When they finally do settle down as 'established' adults, "this adulthood is often more precarious than what is supposed to be 'normal,' what they had hoped and worked for." Stability remains elusive: it is precarious due to economic pressures [ 7 Dollar Crisis], and insufficient due to the steady desire to make possible, for oneself and one's offspring, "a life as we know it, only better." Istiqrär, stability, is "an ideal that you never reach." The attempt to establish oneself and one's family on a higher material and social level than where one came from creates a dynamic of hopes and expectations and steady frustration with the status quo. As a middleaged man from the countryside who has finally managed to establish a home and a family sums up: You work your butt off to achieve it, and then you die. Establishing oneself is therefore a goal regarded with mixed feelings by those pursuing it.

The authorities, the pillars of society, display an equally ambiguous attitude toward the youth (al-shabāb, "a fluid marker that can be used to describe people anywhere between the ages of 15 and 40 years old" [BIRD]). On the one hand, young people's energy and vitality are necessary to maintain the vitality of society and economy, to reproduce itself and thus live on. On the other, their unbridled energy is a potential threat to the existing order of things; combined with the economic pressure they are exposed to, it may turn them into a ticking "time bomb" (AL-SAYYĀD). On the one hand, therefore, both state officials, international consultants, political parties, or grand assemblies such as "The First National Conference for the Youth" (MITWALLİ \& ZALAṬA) regularly call for a greater involvement of "the youth" in order to defuse this threat and to harvest their creative potential—a creativity that the young otherwise amply demonstrate surviving in the informal economy [ $\lambda$ Normality $=$ Heroism (Surviving)]. Psychiatrist 'Áyida Sayf al-Dawla analyses the exhortative rhetoric of glorifying young people as entrepreneurs and persons "willing to work for the sake of the country, with very little in return" as fitting "the notion of a neoliberal contract between governments and citizens that has been globally normalized: the idea that young people will grow up, contribute productively to society and raise families that will in turn do likewise" (BIRD) [ TFreedom vs. Constraint (Individual vs. Collective)]. But while individual achievements are being celebrated (PRIMO) and presented as models to imitate-from internationally successful professionals to the Fatāt al-'Araba, the "Handcart Girl" whose picture, tirelessly pulling her load past the proverbial shabāb il-Pahwa, the lazybones wasting their time in a coffee shop, goes viral on Facebook and earns her an invitation to the Presidential Palace - possibilities for real participation in decision-making and in creating real alternatives to the way things are remain severely restricted (PRIMO; FARAH HOSNY \& PRIMO; SUMAYKa; THE ECONOMiST; AMĪrA FiKRĪ; WAAd AHMED; HonA AL-3ASEMA). Not 
only are they not yet established as responsible adults; novelist Șun'allāh Ibrāhīm notes that there is an "overall perception of the youth as a threat [...] the term 'youth' is used as a substitute for 'revolutionary tendencies' by politicians" (BIRD). Outspokenly antirevolutionary politician Murtadà Manșūr gives voice to a crass moralising disdain shared by some in the establishment: "This is the youth that are wearing tight pants and taking money from their fathers and taking 15 years to graduate from college [...]. They smoke pot. They insult their girlfriends on Facebook. They have no value in this country" (AMINA ISMAIL) [ $\nearrow$ The Honourable Citizen; $\nearrow$ Social Media]. Such contempt provokes anger and frustration. Some try to find creative solutions to this: a Cairo bookshop has set up a special dark room equipped with a full drum kit to allow young Egyptians to "scream their stress away" (ADELA SULIMAN). More normal options, however, are drugs [ $\lambda$ Hashish], "poverty, emigration or, for a minority, jihad" (THE ECONOMIST). The main reason driving many into the arms of radical Islamists, a young Tunisian believes, is the fact that the young are "continuously excluded from any decision-making process" (NOURJAHEN JEMAA). And the son of the Alexandrian clothing presser remembers why he joined the Muslim Brotherhood as a teenager: "My recruiter Khālid gave me a sense of importance and of self-assurance"an appreciation he sorely misses receiving from his own father (AL-NUȘŪR AL-ȘAGHĪRA).

For most, however, it is not radicalization but more subtle forms of insubordination that mark their mood in the face of elders. A cartoon in the semi-official daily al-Ahräm shows a youngster finger-pointing at his private tutor: "You're late today! Next time, you'll need to bring your guardian!" (HASAN) The perception that the young generation 'no longer' unquestioningly submits to the authority of their seniors is widespread, and while this is portrayed as a threat to the stability of the social order by more conservative forces, it is celebrated by activists as the main and lasting achievement of the revolution.

"Almost all films from the region screened at this year's Berlinale festival have a common theme: the narrowness of the traditional social norms that literally deprive the young generation of breathing space. The Arab Spring had the young questioning the old political order, but it was not overcome. While most now believe that the Arab Spring has failed, in the films of Arab directors in their thirties, it is still alive" (WILDANGEL).

The tension between such aspirations and the dominant trend to settle into conventional social norms remains unresolved and a constant source of irritation as well as a creative challenge to strive for change. The 'clash' of 'Young vs. Settled' comes to the fore perhaps most strikingly in the (relatively isolated) cases where unmarried women in their twenties move out of their paternal home to live by themselves or with female friends. A Facebook group ("Femi-Hub") established to help these women in finding a job and a new home attracts some attention. The founders of this group defiantly assert that "this is a very natural step for anyone who has grown capable of choosing a path of self-reliance to achieve one's goals." Most commentators, however, are adamant in that "Arab societies do not allow girls to be independent persons" and that such thoughts lead to "a breakdown of the idea of the family and to social disarray." "This idea will not succeed in our society since it contradicts many norms and customs as well as religious tenets" (DĪNĀ 'ABD AL-KHĀLIQ).

jaig • 21 (2021) - Themed Section In2016: *375-*380 
Quite a few cultural productions illustrate this contrast between the dreams and aspirations of young people and the harsh realities that make it all but impossible to realize these dreams. In the Tunisian short film al-Hufra ("The Pit"), two young men aspire to realize themselves on stage, to perform what they 'really' are, but it proves difficult to get out of the 'pit' they find themselves in. Where is life? Here and now, where I experience it? Or in a beyond where my dreams point to? Or is it out there, where inevitable fate demands me to survive? "I'm afraid of life, it's so hard," confesses one of the two as they must settle for much less than they had hoped for. $\pi$ Suicide rates are rising in Tunisia, particularly among the young (HAMZA MARZOUK; LA PRESSE). The strength of traditional social mores in shaping what people settle for is also shown in the Tunisian film Nhibbak yā Hādi (Hédi), where the protagonist forsakes following the dream of a newly appearing, emotionally exciting, yet insecure future with a spirited, unconventional woman, resigning himself instead to marrying the girl his family has chosen for him, although he feels nothing for her. Beneath a calm and dispassionate surface, inwardly Hādī is boiling and for a while, he leads a double life, but in the end, he gives in to trading risky self-realization and freedom for conventional social safety. The Egyptian writer DīNĀ IBRĀHĪM SHA BĀN's new novel Mudhakkirāt Ğamīla Sa ìd ("Memoirs of Ms Beautiful \& Happy") has a similar theme: a woman's trajectory, between the ages of 15 and 45 , from ambition to turmoil to resigned submission. Such a trajectory where self-realization has to be sacrificed for conformity with established norms has its price, and people are aware of it. It may leave one with an inner void, as in MUHAMMAD ‘ABD AL-NABĪ’s coming-of-age novel Fī ghurfat al-'ankabūt ("In the Spider's Room"). Growing up grappling with confusions, uncertainties, and troubling questions, the protagonist there "barely learns anything from his journey. We see him from childhood through to his forties going through various - but not many — experiences that only add to his uncertainty, barely providing answers to any of the questions that trouble his existence" (SHĀFI'̄i). Toward the end, in a dream, he looks at himself as a new-born baby which he proceeds to uncover, but he

finds nothing underneath, absolutely nothing [...]: this is an almost void person, who only recognizes himself in comparison to others, a person who has something to say about others but not much about himself, a person who stands facing the mirror when he finds out about his mother's informal marriage, unsure how he should feel. (ibid.)

\author{
Related Entries \\ ARRAYs - Apartment Wanted $\downarrow$ Dollar Crisis $\downarrow$ Hashish $\downarrow$ Father Figures $\downarrow$ The Honourable Citizen \\ Migration $\diamond$ Social Media $\diamond$ Suicide \\ CODES - Freedom vs. Constraint (Individual vs. Collective) $\downarrow$ Male vs. Female $\downarrow$ Past vs. Present \\ CODES ColLAPSED - Normality $=$ Heroism (Surviving)
}

jais • 21 (2021) - Themed Section In2016: *375-*380 


\section{References}

\section{Written Sources and Videos}

[The ECONOMIST =] N. N. "The ruining of Egypt: Repression and the incompetence of Abdel-Fattah alSisi are stoking the next uprising", The Economist, August 6, 2016, <https://www.economist. com/leaders/2016/08/06/the-ruining-of-egypt>.

[HONA AL-3ASEMA =] N. N. "Hal 2016 kān `Ām al-Shabāb al-Mișrī?", C[apital] B[roadcast] C[enter], December 25, 2016, <https://youtu.be/3Xa9hrljvQk>.

[JUMHŪRIYYA =]. N. N. "Irtifā' nisbat al-'unūsa fî Tūnis ilà aqșà mu'addalātihā: akthar min milyūnayn wa-rubc milyūn imra'a", November 3, 2016, <https://www.jomhouria.com/art60420

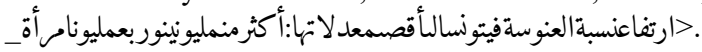

$[$ La PRESSE $=]$ N. N. « Voilà pourquoi les suicides ont augmenté ! », La Presse, September 10, 2016, $<$ https://www.evernote.com/1/AmTzgdRC6H9Et6sZixcFMzCijypn8OLzzQ4>.

Adela SUliman. "Young Egyptians scream their stress away in Cairo bookshop", Reuters, October 25 , 2016, <https://www.reuters.com/article/us-egypt-scream-room-idUSKCN12P1GH>.

AḤMAD NĀĞİ. "Wadā'an li’l-shabāb", Madà, December 18, 2015, <https://www.madamasr.com/

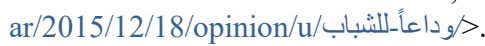

AmINA IsMAIL. "Flamboyant Egyptian politician craves public eye", The New York Times, January 16, 2016, <https://www.nytimes.com/2016/01/17/world/middleeast/flamboyant-egyptian-politiciancraves-public-eye.html>.

AMĪrA FIKRĪ. "Faysbūk yughayyir hayāt 'Fatāt il-'Araba' ilà al-abad", al-'Arab, November 14, 2016, $<$ https://www.evernote.com/1/AmSF d-MRUVPba9zabR9VB9hQP6z-Oj201I>.

BIRD, Laura. "Loyal youth, model citizens", Madà, February 14, 2016, <https://www.madamasr.com/ en/2016/02/14/feature/politics/loyal-youth-model-citizens/>.

DİNĀ ‘ABD AL-KHĀLIQ. “«Femi-Hub» hāribāt min al-ahl bi-sm «al-ḥurriyya»”, al-Wațan, January 1, 2016 , $<$ https://web.archive.org/web/20170309062538/http:/www.elwatannews.com/news/details/891202>.

DīnĀ IBRĀHĪM SHA BĀN. Mudhakkirāt Ğamīla Sa īd, Cairo: Ibdā̄', 2016.

HAmza MARzouk. «Tunisie-2016 : 8661 mouvements sociaux et 792 tentatives de suicide», L'Économiste Maghrébin, December 30, 2016, <https:/www.leconomistemaghrebin.com/2016/ 12/30/tunisie-2016-8661-mouvements-sociaux-792-tentative-de-suicides/>.

HANDAL, Nathalie. " The City and the writer: In Cairo with Yahia Lababidi”, Words without Borders, August 8, 2016, <https://www.wordswithoutborders.org/dispatches/article/the-city-and-the-writerin-cairo-with-yahia-lababidi-nathalie-handal>.

ḤASAN, F.G. "Karīkātēr al-Ahrām al-Yawmī”, al-Ahrām, October 16, 2016, <https://is.gd/f2JKGg>.

Hosny, Farah, and Valentina PRIMO. "16 of 2016: Egypt's real influencers", CairoScene, December 30, 2016, <https://web.archive.org/web/20161231035133/http:// www.cairoscene.com/LifeStyle/ 16-of -2016-Egypt-s-Real-Influencers>.

IBTiHĀL UsĀMA. "Vīdeō... mādhā qāl al-miṣriyūn 'an 2015... Sāì tāksī: '32 sana wi-mish 'ārif atğawwiz’, Shārik, January 1, 2016, <https://sharek.almasryalyoum.com/cities/cairo/470586/>.

Mitwallī, Aḥmad Sāmī, and Shādī 'Abdallāh ZaLAṬA. "al-Sīsī yuṭliq al-Mu’tamar al-Wațan̄i alAwwal li'l-Shabāb al-yawm bi-Sharm al-Shaykh”, al-Ahrām, October 25, 2016, <https:/web.archive.org/web/20161027101913/https:/www.ahram.org.eg/News/192064/135/ 557609/aspx>.

MuHAMMAD `ABD AL-NABī. Fī ghurfat al-'ankabūt, Cairo: Dār al-'Ayn, 2016.

jais • 21 (2021) - Themed Section In2016: *375-*380 
NourJahen JemaA. “An alternative to radicalization”, Tunisia Live, October 20, 2016, <https:// web.archive.org/web/20170426105352/http://www.tunisia-live.net/2016/10/20/an-alternative-toradicalization/ $>$.

PRIMO, Valentina. "4 Mindblowing Egyptian teenage entrepreneurs changing the world at Spark Entrepreneurship Camp", CairoScene, July 21, 2016, <https://web.archive.org/web/20160722122654/ http://www.cairoscene.com/Geek/4-Mindblowing-Egyptian-Teenage-Entrepreneurs-Changing-theWorld-at-Spark-Entrepreneurship-Camp>.

AL-SAYYĀD, Ayman. "Wa-lākinnahū...«'Ām al-Shabāb»”, al-Shurūq, February 7, 2016, $<$ https://www.shorouknews.com/columns/view.aspx?cdate=06022016\&id=ef9bdbe9-66da-42f8a797-fcb10f86e3d5>.

SCHIELKE, Samuli. "Stability as a utopia: Revisiting Egyptian youth as they grow older, and the future tense as time passes", Academic hour, School of Culture and Society, Aarhus University, September 21，2016, <https:/web.archive.org/web/20160922155308/http://cas.au.dk/aktuel/ arrangementer/arrangement/artikel/-5383421b52/>, recording available at $<$ https://soundcloud. com/ustaz-sabry/stability-as-a-utopia>.

SHĀFI'̄̄, Ahmmad. "Riwāyat al-qam" al-muḍādd", Madà, June 2, 2016, <https://www.madamasr.com/

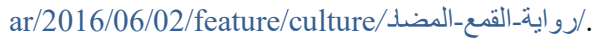

SUMAYKA, Muḥsin. "al-Sīsī yaltaqī 'Fatāt il-'Araba' fī Qașr al-Ittihāadiyya”, al-Mașrī al-Yawm, November 13, 2016, <https://www.almasryalyoum.com/news/details/1039734>.

WAAD AHMED. "Whatever happened in the year of the youth?", Madà, December 28, 2016, <https:// www.madamasr.com/en/2016/12/28/feature/politics/whatever-happened-in-the-year-of-the-youth/>.

WiLDANGEL, René. „Arabische Filme auf der Berlinale 2016. Im Krieg filmt man anders“, Qantara, February 18, 2016, <https://de.qantara.de/inhalt/arabische-filme-auf-der-berlinale-2016-im-kriegfilmt-man-anders $>$.

WORLD BANK. "Unemployment, youth total (\% of total labor force ages 15-24) (modeled ILO estimate) - Egypt, Arab Rep., Tunisia”, June 15, 2021, <https://data.worldbank.org/indicator/ SL.UEM.1524.ZS?locations=EG-TN>.

\section{Fillms}

al-Hufra (The Pit). By Achref Hammami. Tunisia 2016.

Nhibbik Hādī (Hédi). By Muḥammad Bin ‘Ațiyya (Mohamed Ben Attia). Tunisia 2016.

Al-Nușūr al-șaghīra (Little Eagles). By Muhammad Rashād. Egypt/Lebanon 2016.

\albrecht.hofheinz@ikos.uio.no 